\title{
STATUS GIZI, ASUPAN CAIRAN \\ DAN KEBUGARAN JASMANI ATLET \\ DI PERSATUAN BULUTANGKIS KABUPATEN KUDUS
}

\author{
Fitri Rachma - Siti Zulaekah \\ Progam Studi Ilmu Gizi, Fakultas Ilmu Kesehatan \\ Universitas Muhammadiyah Surakarta \\ J1. A. Yani Pabelan Kartasura Tromol Pos I Surakarta 57102 \\ FitriMbakyu25@gmail.com
}

\begin{abstract}
Achievement of badminton athlete performance is supported by excellent physical fitness, normal nutritional status and adequate fluid intake. The purpose of this study was to determine the relationship of nutritional status and fluid intake with physical fitness atbletes in Badminton Association of Kudus Regency. This research is an observational research with cross sectional approach. The populations in the study were badminton athletes in Kudus Region who met the inclusion criteria. Samples used 33 samples from the total population of 85 samples. Analysis of the relationship of nutritional status and fluid intake with athlete's physical fitness using Pearson Product Moment test. Based on the test of the relationship of nutritional status with athlete physical fitness obtained $p$ value $=0.386$. Analysis of the relationship of fluid intake with athlete's physical fitness obtained $p$ value $=0.450$. This study can be concluded that there is no relationship of nutritional status and fluid intake with athlete's physical fitness.
\end{abstract}

Keywords: Nutritional status, fluid intake, physical fitness

\section{PENDAHULUAN}

Bulutangkis dalam pelaksanaannya sangat membutuhkan banyak sekali kemampuan dan keterampilan gerak yang cukup kompleks, diantaranya gerakan berlari ke depan maupun belakang, melompat, melangkah ke penjuru lapangan 
Satatus Giri, Asupan Cairan dan .....

dan memutar badan untuk mengejar shuttlecock sebelum jatuh ke lapangan (Phomsoupha 2015).

Menurut Campos et al (2009), faktor yang harus diperhatikan atlet bulutangkis yaitu ketahanan fisik atau variabel fisik (kelincahan, kelenturan), antropometri, teknik dan taktik bermain serta faktor psikologis. Penelitian yang dilakukan Afifi (2015) menunjukkan bahwa kondisi fisik atlet tunggal putri usia 17-21 tahun tergolong baik dan cukup, tetapi belum memenuhi standar minimal untuk menjadi anggota tim Pelatihan Nasional yang kapasitas fisiknya minimal sangat baik.

Pencapaian prestasi atlet tidak hanya didukung oleh kebugaran jasmani yang prima, tetapi status gizi juga mendukung dalam tercapainya prestasi olahraga. Status gizi dipengaruhi oleh asupan zat gizi. Zat gizi tersebut meliputi zat gizi makro meliputi: karbohidrat, lemak dan protein, serta zat gizi mikro meliputi vitamin, mineral dan cairan (Magirah).

Kebutuhan cairan untuk seorang atlet lebih banyak, karena saat berolahraga (baik latihan maupun bertanding) suhu tubuh meningkat dan akhirnya tubuh menjadi panas. Keluarnya keringat sebagai upaya tubuh untuk mendinginkan tubuh (Rahmawati 2015). Asupan cairan yang berkurang di dalam tubuh menyebabkan menurunnya fungsi paru-paru sehingga respirasi meningkat (Barasi 2007). Keadaan tersebut berpengaruh pada kondisi kebugaran jasmani, karena air yang berfungsi sebagai katalisator tidak bisa membawa oksigen dari paru-paru menuju ke seluruh tubuh (Hermawan et al. 2012). Oleh karena itu, penelitian ini bertujuan untuk menganalisis hubungan status gizi dengan kebugaran jasmani atlet bulutangkis serta menganalisis hubungan asupan cairan dengan kebugaran jasmani atlet bulutangkis.

\section{METODE}

\section{Desain, Waktu, dan Tempat Penelitian}

Jenis penelitian ini termasuk penelitian observasional dengan metode pendekatan cross sectional. Penentuan sampel secara simple random sampling yaitu atlet bulutangkis di wilayah Kabupaten Kudus yang memenuhi kriteria inklus; 
atlet bulutangkis kelompok umur anak-anak dan remaja, pemula, atlet sedang dalam masa latihan (non kompetisi) dan tidak dalam keadaan sakit/cidera, dengan jumlah sampel 33 atlet. Waktu penelitian dilaksanakan pada Bulan April sampai dengan Desember 2016.

\section{Analisis Data}

Jenis data dalam penelitian ini adalah data kuantitatif yang meliputi data status gizi, asupan cairan dan kebugaran jasmani. Sumber data meliputi data primer dan data sekunder. Data primer meliputi data status gizi, asupan cairan dan kebugaran jasmani. Data status gizi diperoleh melalui pengukuran berat badan menggunakan timbangan injak digital, pengukuran tinggi badan menggunakan microtoice. Data asupan cairan diperoleh melalui pengisian kuesioner Food Frequency (FFQ) semi quantitative. Data kebugaran jasmani diperoleh dengan metode beep test. Analisis data menggunakan aplikasi WHO AnthroPlus, Nutrisurvey, dan SPSS 16 for Windows. Hasil uji kenormalan data menggunakan kolmogorof smirnov dan menunjukkan semua data berdistribusi normal, maka dilanjutkan uji hubungan status gizi dan asupan cairan dengan kebugaran jasmani menggunakan uji korelasi pearson.

\section{HASIL DAN PEMBAHASAN}

\section{Karakteristik Subjek Penelitian}

Subjek dalam penelitian ini adalah atlet yang berusia $<18$ tahun di PB. Taurus, PB. Putra Sang Fajar dan PB. Djarum Kudus sebanyak 33 atlet. Terdapat 17 subjek (52,5\%) berjenis kelamin laki-laki dan 16 subjek (48,5\%) berjenis kelamin perempuan. Sebagian besar subjek berumur 13 tahun dengan persentase 42,4\%, sedangkan paling sedikit subjek berumur 17 tahun yaitu sebanyak 3\%.

Status gizi pada penelitian ini dikategorikan menjadi 4 yaitu; sangat kurus jika IMT/U <-3 SD, kurus -3 SD s/d < -2 SD, normal -2 SD s/d 1 SD, gemuk $>1$ SD s/d 2 SD dan obesitas $>2$ SD (Kemenkes RI 2011). Hasil penelitian menunjukkan bahwa status gizi atlet paling banyak adalah normal 
dengan persentase $87,9 \%$, sedangkan kurus sebanyak 3\% dan gemuk sebanyak $9,1 \%$.

Asupan cairan subjek dengan kategori lebih dan kategori kurang memperoleh persentase yang sama banyak yaitu 42,4\%, sedangkan kategori cukup paling sedikit yaitu 15,2\%. Subjek yang memiliki kebugaran jasmani yang paling banyak berdasarkan data tersebut yaitu kategori excellent 30,3\% dan yang paling sedikit adalah kategori di bawah rata-rata 9,1\%.

Tabel 1 Distribusi Karakteristik Subjek berdasarkan Status Gizi

\begin{tabular}{lcc}
\hline \multicolumn{1}{c}{ Variabel } & Jumlah (n) & Persentase (\%) \\
\hline Status Gizi & 1 & 3,0 \\
Kurus & 29 & 87,9 \\
Normal & 3 & 9,1 \\
Gemuk & 33 & 100 \\
Jumlah & & \\
Asupan Cairan & 14 & 42,4 \\
Kurang & 5 & 15,2 \\
Cukup & 14 & 42,4 \\
Lebih & 33 & 100 \\
Jumlah & & \\
Kebugaran Jasmani & & \\
(VO) 2 maks) & 3 & 91 \\
Di Bawah Rata-Rata & 5 & 15,2 \\
Rata-Rata & 8 & 24,2 \\
Di Atas Rata-Rata & 10 & 30,3 \\
Excellent & 7 & 21,2 \\
Superior & 33 & 100 \\
Jumlah & & \\
\hline
\end{tabular}

\section{Hubungan Status Gizi dengan Kebugaran Jasmani}

Pencapaian prestasi atlet tidak hanya didukung oleh kebugaran jasmani yang prima, tetapi status gizi juga mendukung dalam tercapainya prestasi olahraga. Hasil analisis hubungan status gizi dan kebugaran jasmani dengan menggunakan uji Pearson Product Moment menunjukkan nilai $\mathrm{p}=0,386$. 
Berdasarkan hasil analisis tersebut dapat diketahui bahwa nilai $\mathrm{p} \geq 0,05$, artinya Ho diterima sehingga tidak ada hubungan antara status gizi dengan kebugaran jasmani (Tabel 2).

Tabel 2. Hubungan Status Gizi dengan Kebugaran Jasmani

\begin{tabular}{ccccc}
\hline Variabel & Mean \pm SD & Minimum & Maksimum & $\mathbf{P}$ \\
\hline Status Gizi & $0,38 \pm 0,64$ & $-1,83$ & 1,83 & 0,386 \\
Kebugaran Jasmani & $48,78 \pm 7,54$ & 34,70 & 62 & \\
\hline
\end{tabular}

Hasil penelitian ini sesuai dengan hasil penelitian pada atlet bola basket dan Tae Kwon Do di Sekolah Olahraga Ragunan Jakarta yang menyebutkan bahwa tidak ada hubungan antara status gizi dengan kebugaran jasmani atlet (Hanum 2011, Imaduddin 2012). Atlet bola basket yang memiliki status gizi yang kurus, belum tentu memiliki tingkat kebugaran yang rendah, begitupun sebaliknya (Hanum 2011). Pernyataan tersebut sesuai dengan hasil penelitian ini, dimana kategori kebugaran jasmani excellent diperoleh responden dengan status gizi kurus.

Status gizi bukan merupakan salah satu faktor yang mempengaruhi kebugaran jasmani seorang atlet. Beberapa faktor diantaranya yaitu genetik, gaya hidup, diet yang dijalani, latihan, jenis kelamin, usia, komposisi tubuh, kebiasaan olahraga, progam latihan fisik yang terencana dan terorganisir dengan baik, pola recovery atlet yang diantaranya pola tidur teratur, tersedianya fasilitas relaksasi dan asupan gizi yang baik serta kompetensi pelatih (Afifi 2015: Andayani 2012: Campos et al. 2009: Huldani 2012: Wiarto 2015).

\section{Hubungan Asupan Cairan dengan Kebugaran Jasmani}

Kebutuhan cairan untuk seorang atlet lebih banyak, karena saat berolahraga (baik latihan maupun bertanding) suhu tubuh meningkat dan akhirnya tubuh menjadi panas. Keluarnya keringat sebagai upaya tubuh untuk mendinginkan tubuh (Rahmawati 2015). Hasil uji hubungan asupan cairan dan kebugaran jasmani dengan menggunakan uji Pearson diperoleh nilai $\mathrm{p}=0,450$, 
Satatus Giri, Asupan Cairan dan .....

artinya Ho diterima sehingga dapat disimpulkan bahwa tidak ada hubungan antara asupan cairan dengan kebugaran jasmani (Tabel 3).

Tabel 3 Uji Hubungan Asupan Cairan dengan Kebugaran Jasmani

\begin{tabular}{ccccc}
\hline Variabel & Mean \pm SD & Minimum & Maksimum & $\mathbf{P}$ \\
\hline Asupan Cairan & $5831,12 \pm 2129,15$ & 1500,66 & 10481 & 0,450 \\
Kebugaran & $48,78 \pm 7,54$ & 34,70 & 62 & \\
Jasmani & & & & \\
\hline
\end{tabular}

Hasil penelitian yang sejalan yaitu pada cabang olahraga lari tentang pengaruh dari asupan cairan dalam penampilan lari selama 2 jam, menyebutkan bahwa cairan yang dikonsumsi efek osmolaritasnya tidak meningkatkan penampilan atlet lari (Daries et al. 2000). Penampilan yang dimaksud disini adalah kemampuan seorang atlet dalam suatu pertandingan, dimana kondisi fisik atau kebugaran jasmani menjadi indikatornya selain tehnik olahraga.

Asupan cairan bukan merupakan salah satu faktor yang mempengaruhi kebugaran jasmani seorang atlet. Beberapa faktor diantaranya yaitu genetik, gaya hidup, diet yang dijalani, latihan, jenis kelamin, usia, komposisi tubuh, kebiasaan olahraga, progam latihan fisik yang terencana dan terorganisir dengan baik, pola recovery atlet yang diantaranya pola tidur teratur, tersedianya fasilitas relaksasi dan asupan gizi yang baik serta kompetensi pelatih (Afifi 2015: Andayani 2012: Campos et al. 2009: Huldani 2012: Wiarto 2015).

\section{KESIMPULAN}

Berdasarkan hasil penelitian yang dilakukan, dapat disimpulkan bahwa tidak terdapat hubungan antara status gizi dengan kebugaran jasmani atlit. Asupan cairan stlit juga tidak terbukti berhubungan dengan kebugaran jasmani atlit. Kebugaran jasmani stlit dalam penelitian ini diduga dipengaruhi oleh faktor lain 


\section{DAFTAR PUSTAKA}

Afifi SN. 2015. Kondisi Fisik Atlet Bulutangkis Klub Djarum dan Faktor yang Mempengaruhi. [skripsi]. Semarang : Progam Sarjana Universitas Negeri Semarang

Andayani R. 2012. Perbedaan Rerata Nilai VO2max antara Mahasiswa yang teratur Berolahraga dan Mahasiswa yang Tidak Teratur Berolahraga di Universitas Tunas Pembangunan Surakarta. [skripsi]. Surakarta : Progam Sarjana Universitas Muhammadiyah Surakarta

Barasi ME. 2007. At a Glance Ilmu Gizi. Dialih bahasakan oleh Halim H. Jakarta: Erlangga

Campos FAD, Daros LB, Mastrascusa V, Dourado AC, Stanganelli LCR. 2009. Characteristics of Badminton Players. Journal of Biomotricity. 3 (2) : 146-151.

Daries HN, Noakes TD, Dennis SC. 2000. Effect of Fluid Intake Volume on 2-h Running Performances in a 25 Degrees C Environment. Med Sci Sport Exerc 10: 1783-9

Hanum FN. 2011. Hubungan Karakteristik Atlet, Pengetahuan Gizi, Konsumsi Pangan dan Tingkat Kecukupan Gizi terhadap Kebugaran Atlet Bola Basket di SMP/SMA Ragunan Jakarta Selatan. [skripsi]. Bogor : Progam Sarjana Institut Pertanian Bogor.

Hermawan L, Subiyono HS, Rahayu S. 2012. Pengaruh Pemberian Asupan Cairan (Air) terhadap Profil Denyut Jantung pada Aktivitas Aerobik. Journal of Sport Sciences and Fitness. Fakultas Ilmu Keolahragaan Universitas Negeri Semarang. 1 (2): 14 dan 19. ISSN 2252-6528

Huldani. 2012. Status Gizi Mempengaruhi Konsumsi Oksigen Maksimal (VO2Maks) Siswa Pondok Pesantren Darul Hijrah. Hasil Penelitian. 39 (3): 194-195

Imaduddin MAH. 2012. Hubungan antara Karakteristik Atlet, Tingkat Kecukupan Gizi dan Status Gizi dengan Tingkat Kebugaran Atlet Tae Kwon Do di SMA Ragunan Jakarta. [Skripsi]. Bogor : Progam Sarjana Institut Pertanian Bogor 
Satatus Giri, Asupan Cairan dan .....

Kemenkes. 2011. Keputusan Menteri Kesehatan Republik Indonesia tentang Standar Antropometri Penilaian Status Gizi Anak. Jakarta : Kemenkes RI

Magfirah F, Wijanarka A, Arovah NI. Tanpa Tahun. Hubungan Tingkat Pengetahuan Gizi Olahraga, Frekuensi Konsumsi Suplemen dan Status Gizi dengn Kebugaran Jasmani Atlet di Klub Sepakbola PSIM Yogyakarta.

Phoumsoupha M, Laffaye G. 2015. The Science of Badminton: Game Characteristics, Anthropometry, Physiologgy, Visual Fitness and Biomechanics. France: CIAMS-Motor Control and Perception Group, Sport Sciences Department, Universite Paris

Prabowo BH. 2013. Peran PBSI Kudus terhadap Pembinaan Klub Bulutangkis di Kabupaten Kudus Tahun 2013. [skripsi]. Semarang : Fakultas Ilmu Keolahragaan Universitas Negeri Semarang.

Rahmawati, M. 2015. Menu Tepat Makanan Atlet 11 Olahraga Terpopuler. Yogyakarta: Pustaka Baru Press

Ramdhan, RI. 2016. Hubungan antara Status Hidrasi serta Konsumsi Cairan pada Atlet Bola Basket Putra dan Putri Kejurda Kelompok Usia 18 Tahun Kabupaten Indramayu. [skripsi]. Yogyakarta : Fakultas Ilmu Keolahragaan Universitas Negeri Yogyakarta.

Wiarto, G. 2015. Panduan Berolahraga Untuk Kesehatan dan Kebugaran. Yogyakarta: Graha Ilmus 